\title{
Jogpolitika
}

\author{
SZABÓ IMRE SZILÁRD*
}

\section{Jogértelmezési kérdések a szakszervezet jogállásával kapcsolatban}

\author{
szakszervezetek státusza - kollektív szerződés kötésére jogosultak - \\ szervezkedés szabadsága - közvetlen felsőbb szakszervezeti szerv - \\ szakszervezeti tisztségviselő
}

\begin{abstract}
„A szakszervezetek szabályozása meglehetősen felemásra sikerült” - vonja le a végső következtetést a hatályos joganyagról Kiss György „A szakszervezetek jogdogmatikai helyzete és jogpolitikai lehetőségei a magyar munkajogi szabályozás alapján 1992-től napjainkig” címü, 2015-ben megjelent tanulmányában. ${ }^{1}$ Ugyanitt teszi fel a kérdést, hogy „ha a szakszervezet társadalmi szervezet, mennyiben indokolt, illetve szükségszerü a szabályozása?’" Tanulmányomban - a teljesség igénye nélkül - néhány olyan, a gyakorlatban felmerülő jogértelmezési kérdést teszek elemzés tárgyává, melyek plasztikusan világítanak rá arra a kérdésre, hogy a tételes magyar munkajogi szabályozás egyes elemei milyen gyakorlati problémákat vetnek fel, és hogy eltérő értelmezési lehetőségeket nyitnak meg a szakszervezetek jogállásával, illetve jogaik gyakorlásával összefüggésben. Ennek keretében vizsgálom a szakszervezetek jogi természetét, így magát az (elsősorban jogi) meghatározást és a szakszervezet célját, különös tekintettel a „munkaviszonyon túli” szervezkedési lehetőségekre. Ezt követően a jogálláshoz kapcsolódó státuszkérdések és polgári jogi tartalommal is bíró, ugyanakkor munkajogi szempontból idejétmúlt fogalmak bemutatására teszek kísérletet (a „tisztségviselő” és az ún. „felsőbb szerv” értelme-
\end{abstract}

* Dr. Szabó Imre Szilárd tudományos segédmunkatárs, Károli Gáspár Református Egyetem Állam- és Jogtudományi Kar; PhD-hallgató, Pécsi Tudományegyetem Állam- és Jogtudományi Kar; titkárságvezető, Munkástanácsok Országos Szövetsége, Budapest. E-mail: szaboimre90@gmail.com.

1 Kıss György: A szakszervezetek jogdogmatikai helyzete és jogpolitikai lehetőségei a magyar munkajogi szabályozás alapján 1992-töl napjainkig. In: Kiss György (szerk.): Szakszervezetek és kollektív szerződések az új Munka Törvénykönyvében. Akadémiai Kiadó, Budapest, 2015, 11-45.

2 Kıss (2015): i. m., 31. 
zési lehetőségei). Végül a kollektív szerződés megkötéséhez kapcsolódóan a szakszervezeti szövetség kollektív szerződéskötési lehetőségeit vizsgálom, úgy, hogy az egyes vizsgált kérdésekhez de lege ferenda javaslatokat fogalmazok meg.

\section{A szakszervezetek fogalma és jogi természete}

A szakszervezet a munkavállalóknak az ún. koalíciós szabadság mint „univerzális emberi jog alapján létrejövő"3 sajátos társadalmi szervezete, amelynek célja a munkavállalók érdekeinek előmozdítása és védelme. ${ }^{4} \mathrm{~A}$ koalíciós szabadsághoz és a szabad szervezkedéshez kapcsolódó szakszervezeti jogokat nemzetközi egyezmények ${ }^{5}$ és az Európai Unió joga ${ }^{6}$ is biztosítja. Magyarországon a munkavállalók szervezkedési szabadságát az Alaptörvény garantálja, ${ }^{7}$ melynek fö tartalmát, a szakszervezetek jogállását a Munka törvénykönyvéröl szóló 2012. évi I. törvény (a továbbiakban: Mt.) szabályozza.

A koalíciós szabadság alapján létrejövő szervezet (így a szakszervezet) fogalmi ismérvei a szervezett akaratképzés, az önkéntesség, a konkrét cél és a meghatározott - a tagoktól elkülönült - szervezet (minimális létszámmal és nyilvántartott tagsággal), mely nem áll olyan külső befolyásolás vagy korlátozás alatt, ami gátolja jogainak szabad gyakorlását, így garantálva független müködését. ${ }^{8} \mathrm{~A}$ szakszervezeti képviselet elsődleges tárgya a munkavállalói érdekvédelem mint a szakszervezet klasszikus funkciója, melyből fakadó speciális jogok rendeltetésénél fogva megilletik. A különböző szakszervezeti típusokat igen nehéz kategorikusan meghatározni és azokat tipizálni, ezáltal teljes körü képet kapni az egyes országok gyakorlatáról. Fontos azt is hangsúlyozni, hogy a szakszervezetek a mindenkori gazdasági és társadalmi körülményeknek megfelelően más és más szerveződési formákkal kísérleteznek. ${ }^{9}$ A szakszervezetek - feladatuk és küldetésük szerint - elsősorban a

3 Czuglerné Ivány Judit-Kun Attila-Szabó Imre Szilárd: Az alternatív vitarendezés alanyai a munkavállalói oldalon; mitöl kollektív egy érdekvita? (szakszervezet, üzemi tanács). HVG-ORAC, Budapest, 2017, 27. Vö. az ILO Nyilatkozata: A munka világára vonatkozó alapvető elvekről és jogokról, 1998.

${ }^{4}$ Nemzetközi Munkaügyi Szervezet/International Labour Organisation (ILO) - az egyesülési szabadság és a szervezkedési jog védelméröl szóló 87 . sz. egyezménye 10. cikk.

5 A személyek szervezkedési jogával összefüggésben alkalmazandóak az ILO 87. sz. és az egyéb szervezkedési szabadságra vonatkozó egyezményei is (például a szakszervezeti tisztségviselők védelméről és munkaidő-kedvezményéröl szóló 135. sz. egyezmény), esetenként bizonyos szük korlátokkal (a kollektív tárgyalásra és a sztrájkjogra vonatkozóan - a 98. és a 151. sz. egyezmények).

6 Az Európai Unió Alapjogi Chartájának 12. cikke. Az Európai Unió müködéséről szóló szerződés (EUMSZ) 151-156. cikke. Ugyanakkor az Európai Unió jogrendjének is egyfajta sajátossága a közösségi jogalkotás folyamata, melyben a munkajogot érintő irányelvek kialakításában megkerülhetetlen szerep jutott a szakszervezeteknek. Lásd bővebben Kıss György: Az Európai Unió munkajoga. Osiris, Budapest, 2002; BARnARD, Catherine: EU Employment Law. Oxford University Press; 4. edition, Oxford, 2012.

7 Magyarország Alaptörvénye VIII. cikk (2) és (5) bekezdés.

8 Kiss György (szerk.): Munkajog. Budapest, Osiris, 2005, 343-348.

9 Napjainkban „....egyrészt megjelennek az innovatív, nyitott, hálózat-jellegủ szervezkedési logikát képviselő szakszervezetek és egyéb alternatív jellegủ, rugalmas érdekképviseleti struktúrák... Másrészt a platformgazdaságban is kimutathatóak a kollektív alku csírái... Harmadrészt a sztrájkok és kollektív akciók újszerü alakzatai is felszínre törnek...” E jelenségeket gyakran nevezik a szakirodalomban „alternatív” szakszerve- 
gazdasági és szociális érdekvédelem eszközei, másodlagosan - társadalmi súlyuk és beágyazottságuk következtében - a jogalkotásra is hatással bíró, tömegmozgalmi tevékenységet is gyakran folytattak a foglalkoztatással és szociális jogokkal összefüggő kérdésekben a 20. századi tömegmozgalommá válásukat követően. ${ }^{10}$ Gladstone, Pankert és Yemin ${ }^{11}$ az ILO álláspontját képviselve azt emelik ki, hogy a hagyományosan a munkáltató-szakszervezet közötti (ún. bipartit) tárgyalásra alapozott szakszervezet fogalom „új dimenziót nyert a jóléti állam kiépülésével, aminek nyomán mind nagyobb szerepet kaptak az országos szintü (ún. tripartit), a kormány részvételével a munkáltatók és munkavállalók érdekei szempontjából fontos gazdasági és szociális kérdésekről folytatott tárgyalások". ${ }^{12}$

A szakszervezeti jogok mindezen sajátosságok mellett nem képeznek egy zárt, taxatív, pontosan körülhatárolható rendszert, ráadásul az azonos elnevezéssel bíró jogok tartalma és hatása is eltérő lehet, sőt még egy adott országon belül a különböző területeken kodifikált jogok sem azonosak (például magánszféra-közszféra). ${ }^{13}$

Magyarországon a szakszervezetek az egyesület jogi formájában végzik tevékenységüket, annak egy különös típusaként. A fent hivatkozott ILO egyezményből és a hazai jogi szabályozásból ${ }^{14}$ következően nem az elnevezésétől válik egy társadalmi szervezet szakszervezetté (mely szót nem is szükséges szerepeltetni annak nevében; viselheti akár a munkástanács, ${ }^{15}$ a liga, az érdekvédelmi szervezet vagy más elnevezést is), ahhoz a munkavállalói érdekvédelmi rendeltetés (mint szervezeti cél) szükséges. ${ }^{16} \mathrm{Az}$ érdekvédelem (mint a szakszervezeti képviseleti jogviszony általános tárgyköre, mely egyfajta ellenállásra, a munkáltatóval a sajátos helyzetből

zeti tevékenységnek (Alt Labour). Kun Attila: Munkajogviszony és digitalizáció: rendszerszintű kihívások és a kezdetleges európai uniós reakciók. In: Pál Lajos-Petrovics Zoltán (szerk.): Visegrád 15.0: A XV. Magyar Munkajogi Konferencia szerkesztett előadásai. Wolters Kluwer, Budapest, 2018, 408.

10 A szakszervezetek kvázi politikai szerepvállalásainak más aspektusairól lásd DAVIES, Paul-FrEEDLAND, Mark: Kahn-Freund's Labour and the Law. Stevens \& Sons, London, Third Edition, 1983; WRIGLEY, Chrid: Labour and Trade Unions in Great Britain, 1880-1939. In: Digby A.-Feinstein C.-Jenkins D. (eds.): New Directions in Economic and Social History. Palgrave, London, 1992; Busch, Gary K.: The Political Role of International Trade Unions. Macmillan, London, 1983; Degryse, Christophe-TILly, Pierre: 1973-2013: 40 years of history of the European Trade Union Confederation. European Trade Union Institute, Brussels, 2013; Lux Judit: A magyarországi szakszervezetek történetéből. Átdolgozott kiadás, Friedrich Ebert Alapítvány, Budapest, 2008.

11 Gladstone, Alan-Pankert, Alfred-Yemin, Edward: A munkaügyi kapcsolatok rendszere az iparilag fejlett piacgazdaságokban. In: A munkavállaló, a munkáltató és az állam. Munkaügyi Kutatóintézet, Budapest, 1989, 138-189.

12 То́тн András: Civil társadalom és a szakszervezetek. Szociológiai Szemle, 1995/3, 21-50. http://www. szociologia.hu/dynamic/9503toth.htm (2019. 06. 27.).

13 KendeREs György: A szakszervezeti jogok elemző bemutatása magyar és nemzetközi vonatkozásban. Miskolci Jogi Szemle, 2017/2, különszám, 258; Kiss (2005): i. m., 360.

14 Ectv. 4. § (1).

15 A Munkástanácsok Országos Szövetségéhez tartozó szakszervezetek meghatározó része viseli a „Munkástanács" elnevezést, mely mozgalom történetisége az 1956-os forradalom és szabadságharcig nyúlik vissza.

16 „A Legfelsőbb Bíróság már a BH 1992, 499. itéletében rögzítette, hogy szakszervezeten (érdekképviseleti szervezeten) nemcsak a szakszervezetet, hanem az egyéb elnevezésü olyan munkavállalói érdekképviseleti szervezetet is érteni kell, amelynek célja a munkavállalók érdekeinek elömozdítása és védelme." BANKó Zoltán-BERKE Gyula-Kıss György: Kommentár a munka törvénykönyvéhez. Wolters Kluwer, Budapest, 2017, 785. 
fakadó konfrontatív szembenállásra is utal) és az érdekképviselet (a tevékenység jogi formájára utaló szó, amely a tag és a szakszervezet között fennáló joggyakorlási közvetettséget fejezhet ki ${ }^{17}$ ugyanakkor nem szinonim fogalmak. Az érdekképviselet Román László meghatározása szerint „abban az értelemben egy sajátos státusfogalom, hogy az adott joggyakorló joghelyzetére (csupán képviselöi pozíciójára) utaló jogi kifejezés".

A szakszervezet alapítására, szervezetére, annak változásaira, illetve magára a müködésre is az egyesületekre vonatkozó szabályok vonatkoznak, így jogállására alkalmazni kell a Polgári Törvénykönyvröl szóló 2013. évi V. törvény (a továbbiakban: Ptk.) egyesületekre vonatkozó rendelkezéseit, illetve a 2011. évi CLXXV. törvényt az egyesülési jogról, a közhasznú jogállásról, valamint a civil szervezetek müködéséről és támogatásáról (a továbbiakban: Ectv.). A szakszervezetek bejegyzésével és a szabad szervezkedéssel kapcsolatban az állami hatóságok kötelesek tartózkodni minden beavatkozástól, ami ezt a jogot korlátozná vagy törvényes gyakorlását gátolná. ${ }^{18}$ Mindemellett a szakszervezet autonóm müködésébe tartozik, hogy milyen belső szervezettel, struktúrával kíván müködni, ezeket az alapszabályában (az egyesületekre vonatkozó joganyag minimális tartalmi követelményének megfelelöen) szabadon alakíthatja ki. Ennek elkerülhetetlenül fontos szerepe van a munkajog területén, a jogaik gyakorlásában is [lásd később a tisztségviselöi kör, az (alap)szervezeti struktúra és a működési terület(ek) kialakításánál].

A posztszocialista országokra különösen jellemzö, hogy a szakszervezetek törvényi szabályozása kvázi „demonstrálja” a szakszervezetek jogpolitikai szerepét. ${ }^{19}$ Noha a szakszervezet jogállásának általános szabályozása a munkajog területén érdemben nem változott a 2012-es Mt. hatálybalépésével, a törvény egyes vélemények alapján alapvetően változtatja meg a szakszervezet munkahelyi jelenlétének helyzetét. ${ }^{20} \mathrm{~A}$ törvényben biztosított jogok - a korábban hatályos 1992. évi XXII. törvénytől (a továbbiakban: 1992. évi Mt.) eltérően - nem általánosságban „a szakszervezeteket", hanem a munkáltatónál képviselettel rendelkező szakszervezetet illetik meg (lásd a 4. pontban). A szakszervezet jogait (nem érintve a szakszervezeti tisztségviselök védelmére vonatkozó rendelkezést) a hatályos Mt. csekély tartalommal tölti meg, „a jogalkotó arra a minimális szintre redukálja, amely általában megillet egy meghatározott cél érdekében müködő társadalmi szervezetet". ${ }^{21}$ Álláspontom szerint szimbolikus üzenettel bír az is, hogy a szakszervezetekre vonatkozó joganyag a törvény végén kapott helyet, az üzemi tanácsokra vonatkozó szabályozást követően.

17 RomÁn László: A munkajog alapintézményei. III. kötet. Janus Pannonius Tudományegyetem Állam- és Jogtudományi Kar, Pécs, 1997, 82.

18 1948. évi 87. ILO egyezmény 3. cikk.

19 A szocialista rendszer összeomlását követő „átmenet” okozta kihívásokra lásd TRAUB-MERz, Rudolf-PRINGLE, Tim (eds.): Trade unions in transition: From command to market economies. Friedrich-Ebert-Stiftung, Berlin, 2018.

20 KISs (2015): i. m., 182.

21 KIss (2015): i. m., 182. 


\section{Munkavállalók és a „szürke zóna” - Kit képviselhet a szakszervezet?}

Az Mt. alapján szakszervezet a munkavállalók minden olyan szervezete, amelynek elsődleges célja a munkavállalók munkaviszonnyal kapcsolatos érdekeinek elömozdítása és megvédése. ${ }^{22}$

Munkavégzés mindazonáltal nem csak munkaviszonyban, azaz munkaszerződésen alapuló jogviszonyban képzelhető el. ${ }^{23} \mathrm{~A}$ hivatkozott 87 . sz. ILO egyezmény is tágan értelmezi a munkavállaló fogalmát (maga a workers kifejezés is ezt tükrözi). A „szakszervezetiség” kapcsán ugyanakkor a legfontosabb a fent megjelölt érdekek elömozdítása és azok védelme, ami elsősorban az alárendelt (függő) helyzetből fakad. Az ILO-nak az egyezmények és ajánlások végrehajtásával foglalkozó szakértői bizottsága ${ }^{24}$ és kifejezetten a Szervezkedési Szabadság Bizottsága ${ }^{25}$ számos esetben foglalkozott az egyezmények gyakorlati megvalósulásával. A bizottságok „következetesen érvelnek azon álláspont mellett, hogy a nem munkavállalónak minősitett munkavégző személyek is teljes mértékben élvezzék a taglalt egyezményekből származó szakszervezeti, szervezkedési jogokat, mégpedig az érdekeik előmozdítása és védelme érdekében, kollektív alku által." ${ }^{26} \mathrm{~A}$ szakértői bizottság 2016-ban megjelentetett megállapításában egészen odáig ment, hogy kifejezetten kimondta: a 98. számú Egyezmény 4. cikke alapján a kollektív alkuhoz való jogot az önfoglalkoztatókat képviselő szervezetek számára is biztosítani kellene. ${ }^{27}$

A szakszervezetek a gyakorlatban egyre inkább felvállalják minden gazdaságilag függő munkavállaló és az önfoglalkoztatók érdekeinek védelmét is, mely szervezkedésben új kihívást jelentenek az újonnan megjelenő foglalkoztatási formák is. ${ }^{28}$ Ebbe a körbe sorolhatóak a munkavállaló jogállásához hasonló jogállású személyek ${ }^{29}$ szervezetei, akik kollektív megállapodásokat kötnek a munka megrendelöivel. Ugyanakkor „az önfoglalkoztatók szervezkedési szabadságát (és még inkább kollektív alkuhoz való jogát) a versenyjog értelemszerủen korlátozhatja bizonyos mér-

22 Mt. 270. $\$(1)$ bekezdés.

23 Erről bővebben: GyulavÁRI Tamás: A szürke állomány - Gazdaságilag függő munkavégzés a munkaviszony és az önfoglalkoztatás határán. Pázmány Press, Budapest, 2014; SzEKEREs Bernadett: Munkajogon innen munkaviszonyon túl. A gazdaságilag függő önfoglalkoztatás és annak munkajogi védelme. PhD-értekezés, Miskolci Egyetem Állam- és Jogtudományi Kar, Miskolc, 2018.

24 Committee of Experts on the Application of Conventions and Recommendations (CEACR).

25 A kifejezetten a 87. és 98. számú egyezmények végrehajtásával és megfelelőségével foglalkozó Committee on Freedom of Association (CFA).

26 RÁcz Ildikó: A kollektív jogok érvényesülésének lehetőségei a platform-munkavégzés esetében. Miskolci Jogi Szemle, 2018/2, 147.

27 http://www.ilo.org/dyn/normlex/en/f?p=NORMLEXPUB:13101:0::NO::P13101_COMMENT_ID:3082151 (2019. 06. 27.). Bövebben RÁcz: i. m.

28 „Employees, workers, the self-employed (bogus or otherwise) do not exist in rerum natura." CountouRIS, Nicola-De Stefano, Valerio: New trade union strategies for new forms of employment. ETUC, Brussels, 2019, 19

29 A hazai szabályozással kapcsolatos kihívásokról bővebben lásd Kıss György: A munkavállalóhoz hasonló jogállású személy problematikája az Európai Unióban és e jogállás szabályozásának hiánya a Munka Törvénykönyvében. Jogtudományi Közlöny 2013/1, 1-14; GYULAVÁRI Tamás: A gazdaságilag függő munkavégzés szabályozása: Kényszer vagy lehetőség? Magyar Munkajog E-folyóirat, 2014/1, 1-25. 
tékben". ${ }^{30}$ Ilyen megállapodások léteznek Ausztriában, Németországban, de másutt is. ${ }^{31}$ Tradicionálisnak tekinthető ebben a tekintetben a német tarifaszerződési törvény (Tarifvertragsgesetz, TVG) 12a. §-a, amely az „Arbeitnehmerähnliche Personen” címet viseli. ${ }^{32} \mathrm{~A}$ rendelkezés a tarifaszerződési törvényt alkalmazni rendeli az ún. munkavállalóhoz hasonló jogállású személyek esetében is. E személyi kör - meglehetősen bonyolult - tételes jogi meghatározásának lényeges tartalma az, hogy olyan személyekről van szó, akik gazdaságilag függő helyzetben vannak, a munkavállalóhoz hasonlóan szociális védelemre szorulnak, tevékenységüket megbízási vagy vállalkozási szerződés alapján végzik, személyesen teljesítenek, és túlnyomórészt egy meghatározott személy számára végeznek munkát, vagy munkajövedelmüknek átlagosan legalább fele ettől az egy személytöl származik. ${ }^{33}$ A TVG tehát megnyitja azt a lehetőséget, hogy e személyek érdekképviseletei kollektív szerződést kössenek a megbízói, megrendelői oldal érdekképviseleteivel. ${ }^{34}$

Hazánkban kétséges, hogy ilyen tartalmú megállapodások egyáltalán érvényesen létrejöhetnek-e, és az ilyen irányú szervezkedési kísérletek is kezdetlegesek. 2018-ban alakult meg a Magyar Mozgóképkészítők Szakszervezete, melynek alapszabálya tartalmazza, hogy „tagjai a magyar televíziózással és filmkészítéssel, vagy más területen mozgóképkészítéssel és annak kiegészítö feladataival foglalkozó személyek, akik a szervezet céljaival és értékeivel egyetértenek és támogatják azt". ${ }^{35}$ A mozgóképalkotás, a film-, video-, televízióműsor-gyártás területe kifejezetten érintett a feketefoglalkoztatással összefüggő jogsértésekkel, különösen a színlelt szerződéssel történő foglalkoztatás problémájával, amely jogellenes „gyakorlatnak” a megváltoztatását tűzte ki célként a szakszervezet. Hasonló kihívások övezik a 2015-ben alakult, és a személygépkocsival történő személyszállításra vonatkozó jogszabályok átalakításáért küzdö ${ }^{36}$ Magyar Taxisok Szakszervezetének tevékenységét, ${ }^{37}$ amely szervezet célja szerint a szervezkedési körébe tartozó „egyéni vállalkozók, gazdasági társaságok, valamint munkavállalók (tagok) részére a vállalkozási és szolgáltatási (munkavégzési) körülményekhez kapcsolódó szakmai alapon szerveződő" érdekképviseletét látja el. Noha a hazai jogi szabályozás - tipikusan - nem tekint munkavállalóként a taxisokra, a taxistársadalom (mint egyfajta érdekközösség) részéről időnként mégis megszervezésre kerülnek komoly érdekérvényesítés-

30 Kun Attila: A digitalizáció kihívásai a munkajogban. In: Homicskó Árpád Olivér (szerk.): Egyes modern technológiák etikai, jogi és szabályozási kihívásai. Károli Gáspár Református Egyetem Állam- és Jogtudományi Kar, Budapest, 2018, 134. Vö. C-413/13 sz. FNV Kunsten Informatie en Media ügyben 2014. december 4-én hozott ítélet, ECLI:EU:C:2014:2411.

31 Kiss György (szerk.): Munkajog (kézirat), Dialóg Campus, Budapest, 2019, 383.

32 A rendelkezés eredete az 1900-as évek elejére megy vissza, és a TVG-be - számos tételes jogi előzményt követően - 1974-ben iktatták be. Lásd Brecht-Heitzmann, Holger-Kempen, Otto Ernst-Schubert, Jens Martin-Seifert, Achim (Hrsg.): Tarifvertragsgesetz. Bund Verlag, Frankfurt am Main, 2014, 1694.

33 TVG 12a. § (1) bekezdés. Egyes tevékenységek (például újságírás) esetében alacsonyabb jövedelem is megalapozhatja, hogy a tevékenységet végzök a törvény hatálya alá kerüljenek.

34 A rendelkezés ez idő szerinti gyakorlati jelentőségét elsősorban a médiaiparban látják. Lásd BrechtHeitzmann-Kempen-Schubert-Seifert: i. m., 1696.

35 http://mmksz.hu/wp-content/uploads/2018/04/alapszably.pdf (2019. 06. 27.).

$36 \mathrm{http} / / /$ kamaraonline.hu/cikk/uj-taxisrendeletet-kovetel-a-magyar-taxisok-szakszervezete (2019. 06. 27.).

37 A területen működik még a Taxis Gépkocsivezetők Független Szakszervezete. 
sel összefüggő, nyomásgyakorló, ún. direkt munkaügyi akciók, melyek határozott nyomást jelentenek a kormányzatra is. Gondoljunk csak a legutóbbi Uber-vitára, melynek végén a személyszállítási szolgáltató a piaci pozícióit feladva vonult ki Magyarországról. ${ }^{38}$

Szintén érdekes problémát vet fel, ha a fejezet címétöl eltérően azt kérdezzük, hogy kiket nem képviselhet a szakszervezet? A rendvédelmi feladatokat ellátó szervek hivatásos állományának szolgálati jogviszonyáról szóló 2015. évi XLII. törvény (a továbbiakban: Hszt.) - a korábban hatályos szabályozástól eltérően ${ }^{39}$ - kimondja, hogy a polgári nemzetbiztonsági szolgálatok hivatásos állományának tagja szakszervezetnek nem lehet tagja, a polgári nemzetbiztonsági szolgálatoknál a hivatásos állomány érdekvédelmére szakszervezet nem müködhet ${ }^{40}$ ezzel teljesen kizárva az egyesülési jog speciális, szakszervezeti jogának a gyakorlását.

Két érdekvédelmi szervezet 2016-ban közös beadvánnyal fordult az alapvető jogok biztosához, kérve, hogy az Alkotmánybíróság eljárását kezdeményezze. ${ }^{41}$ A panaszosok az alaptörvény-ellenességet a hazai és a nemzetközi jogforrásokra (az ILO 87., 98. és 151. számú egyezményére) hivatkozással tartják alkotmányellenesnek. A Belügyminisztérium álláspontja szerint a szolgálati jogviszony bizalmi jellege zárja ki a szakszervezetek müködését, ami egyben lehetetlenné teszi célja szerinti feladatainak ellátását is, mivel a polgári nemzetbiztonsági szolgálatoknál a munkatársak sem lehetnek tisztában más munkatársak feladataival, a foglalkoztatás körülményeivel, mivel ezek minősített adatot képezhetnek. Ezen indokolás mentén a minisztérium a szakszervezeti tagi nyilvántartásokban történő személyes adatok kezelését is ellentétesnek tartja az állomány tagjainak többségében védett jellegével, továbbá a biztos jelentése szerint "nem szerencsés” a polgári nemzetbiztonsági szolgálatot teljesítő hivatásos állományú személy(ek) szakszervezeti vezetőként való közszereplése sem. Az alapvető jogok biztosa vizsgálata során megállapította, hogy noha a felsorolt ILO egyezmények szűk körben (fegyveres erők és a rendőrség) engednek bizonyos kivételeket a szervezkedés szabadságának általános biztosítása alól, az ugyanakkor ebböl nem vezethető le, hogy a korlátozás a szervezetalakítás tilalmát (magyarán a jog totális kiüresítését) jelentse, ugyanis a nemzeti jogalkotónak biztosítania szükséges az alapjoggyakorlási minimumot. A jelentés azt is megjegyzi, hogy ezen kivételek nem alkalmazhatóak a polgári nemzetbiztonsági szolgálat hivatásos állományú tagjaira; tekintve, hogy a polgári nemzetbiztonsági szolgálatok mind az Alaptörvényben való rendszertani elhelyezésüket, mind funkciójukat tekintve eltérnek a fegyveres erőktöl és a rendőrségtöl. Az egyezményben foglalt „kivételek” pedig nem értelmezhetőek kiterjesztő módon. Külön érdekesség, hogy mivel sem a Hszt., sem az Ectv. nem rendelkezik a területen müködő szakszer-

38 FodoR T. Gábor-NÁdAS György-SzABÓ Imre Szilárd: Kollektív munkaügyi viták és az alternatív vitarendezés lehetöségei a közúti közlekedés területén. HVG-ORAC, Budapest, 2018, 18-20.

39 Az 1996. évi XLIII. törvény a fegyveres szervek hivatásos állományú tagjainak szolgálati viszonyáról is alkalmazott korlátozásokat - 281. § (1), 282. §-, melyek álláspontom szerint megfeleltek a hivatkozott ILO egyezményeknek.

40 Hszt. 333. § (1) bekezdés.

41 Az alapvető jogok biztosának jelentése az AJB-2047/2016. számú ügyben. Lásd még MÉLYPATAKı Gábor: A szakszervezetek szerepe és lehetősége a közszolgálatban. Új Magyar Közigazgatás, 2018/2, 84-85. 
vezetek sorsáról, így azok a Ptk.-ban meghatározott, az egyesületek megszünésére vonatkozó rendelkezésekkel nincsenek összhangban, ami további jogi bizonytalanságot eredményez. Noha az alapvető jogok biztosa a jelentésben feltárt visszásságok orvoslása érdekében felkérte a belügyminisztert a jogszabályi környezet módosítására, oly módon, hogy az tegye lehetővé az Alaptörvényben meghatározott jog gyakorlását, eddig intézkedés (jogalkotás) nem történt.

\section{A szakszervezeti „tisztségviselő” fogalmának munkajogi tartalma}

A szakszervezeti tisztségviselő fogalmának rendkívül fontos jelentősége van a munkajogi szabályozás területén, ${ }^{42}$ ugyanakkor a fogalomnak nincs tételes jogi definíciója. A tisztségviselők - az általánosan elfogadott értelmezés szerint - a szakszervezet azon tagjai, akik a szakszervezet életében kulcsfontosságú feladatokat töltenek be, és akiket a szakszervezet alapszabálya szerint, az abban jelölt megbízatásra megválasztottak. ${ }^{43}$ Megjegyzem ugyanakkor, hogy a tisztségviselöi minőséghez még tagsági jogviszony sem szükséges. A Ptk. a vezető tisztségviselői megbízás keretében lehetővé teszi, hogy az alapszabály felhatalmazása alapján a vezető tisztségviselők legfeljebb egyharmada az egyesület tagjain kívüli személyekből is megválasztható legyen. A munkáltatónak az érdekképviselet autonómiájából és függetlenségéből fakadó - a tisztségviselő személyére vonatkozó - döntését tudomásul kell vennie, abba nincs beavatkozási, befolyásolási lehetősége, ${ }^{44}$ és a megválasztás szabályszerűségének bizonyítását sem kérheti. A tisztségviselő ugyanakkor - a közkeletű téves értelmezéssel szemben - nem feltétlenül azonos a szakszervezet ügyvezető szervében tisztséget betöltő személyekkel (például elnökségi tagokkal), vagy - amennyiben létezik - a felügyelö bizottság tagjaival. Ugyanakkor tisztázatlan e tekintetben a szakszervezet (elsősorban belső) munkatársainak, szakértőinek (például szakszervezeti jogtanácsos) státusza. A polgári jogi képviselet fogalma is eltérő tartalommal bír. A szakszervezet nevében (természeténél fogva) a létesítő okiratban (alapszabályban) feljogosított személy tehet jognyilatkozatot. Törvényes képviselő lehet a vezető tisztségviselö, ${ }^{45}$ vagy ha a jogi személy létesítő okirata vagy szervezetére és müködésére vonatkozó belső szabályzata a jogi személy szervezetén belül képviseleti joggal járó tisztséget határoz meg, akkor e tisztség betöltője a jogi személy önálló képviselője (szervezeti képviselö). ${ }^{46}$

Tisztségviselésre ennél tágabb körben is lehetőséget lehet biztosítani, azonban az alapszabálynak (mint legfőbb statútumnak) megfelelően tartalmaznia kell (például az alapszervezeti struktúra felsorolásával), hogy mi módon válik jogosulttá az adott munkáltatóval munkaviszonyban álló személy, hogy védett tisztségviselöként kerüljön megjelölésre, vagy „rajta keresztül” feleljen meg - az addig jogok gyakorlására nem képes - érdekképviselet a munkáltatónál képviselettel rendelkező szak-

42 Lásd Mt. 232. §, 270. § (2) b), 273. §, 294. § (1) e).

43 Gyulavári Tamás (szerk.): Munkajog. ELTE Eötvös Kiadó, Budapest, 2016, 443.

44 EBH 2007, 1631; EBH 2004, 1147.

45 Ptk. 3:29. §.

46 Ptk. 3:30. §. 
szervezet jogi státuszának, az Mt. „tisztségviselővel rendelkezik”"47 fordulata alapján (lásd lentebb). Ez a kérdés rendszerint felmerül a szakszervezet alapszervezetében tisztséget vállaló személyek esetében, amit a szakszervezeti zsargon „titkár” vagy éppen „bizalmi” kifejezéssel illet.

A korábbi Mt. hatálya alatt felmerült a jogalkalmazásban, ${ }^{48}$ hogy bizonyos esetekben szakszervezetek „visszaélhettek” ezzel a lehetőséggel; azaz felmerült, hogy a tisztségviselők számának meghaladásával (nagy számával) a szakszervezet túllépte-e az érdekképviseleti tevékenység által indokolt és észszerü mértéket. Az Mt. a védelemben részesülő tisztségviselök számát jelenleg nem a taglétszámhoz köti, hanem az üzemi tanácsok struktúrájához hasonlóan, telephelyi szabályokat alkalmazva, a telephelyen dolgozó munkavállalók létszámához (korábban a védelem bármely tisztségviselő számára - számbeli korlátok nélkül - elérhető volt). A telephelyhez történő igazítás újabb ellentmondásokkal jár, miközben további igazságtalanságokat eredményez, például a regionális egységgel rendelkező vállalatoknál, ahol 4000 fö felett már nem nő a munkajogi védelemben részesülők száma. ${ }^{49} \mathrm{E}$ mögött az a vélekedés állhat, mely szerint korábban túlzottan magas volt a védett tisztségviselők száma. Egyetértek ugyanakkor azokkal a kritikai véleményekkel, melyek szerint az érdekképviselethez kapcsolódó feladatok mennyisége és így a munkajogi védelem rendeltetése sokkal inkább függ a szakszervezet taglétszámától, mint a munkavállalói létszámtól, ${ }^{50}$ ezért az ehhez (a munkavállalói létszámhoz) kapcsolódó szabályozást ${ }^{51}$ is érdemes lenne felülvizsgálni. ${ }^{52}$

Kedvező változásként lehet tekinteni arra az „újdonságra”, mely szerint a munkaidő-kedvezményt a szakszervezet által megjelölt munkavállaló veheti igénybe (a korábbi Mt. ezt a szakszervezeti tisztségviselők számára biztosította). ${ }^{53} \mathrm{~A}$ hatályos szabályok szerint a naptári évenként igénybe vehetö összes munkaidő-kedvezmény a munkáltatóval munkaviszonyban álló minden két szakszervezeti tag után havi egy órára módosult.

Az Mt. külön nevesíti - a munkajogi védelemmel rendelkező - szakszervezeti tisztségviselők ${ }^{54}$ munkaidő-kedvezményét, amely a munkáltatóval való konzultáció teljes tartamára szól. ${ }^{55}$ Ennek tartama nem számít bele a munkaidő-kedvezmény mértékébe, így azt kvázi „pluszként” a tagok után érvényesíthető munkaidő-kedvez-

47 Mt. 270. $§(2)$ bekezdés.

$48 \mathrm{EBH} 2003,967$.

49 Mt. 273. § (3) bekezdés.

50 KÁRTYÁs Gábor: A szakszervezeti tisztségviselők munkajogi védelme és legújabb fejleményei. In: Bankó Zoltán-Berke Gyula-Tálné Molnár Erika (szerk.): Quid Juris? Ünnepi kötet a Munkaügyi Bírák Országos Egyesülete megalakulásának 20. évfordulójára. Pécsi Tudományegyetem Állam- és Jogtudományi Kar Kúria - Munkaügyi Bírák Országos Egyesülete, Pécs-Budapest, 2018, 207.

51 Mt. 273. § (3) bekezdés.

52 A szakszervezetek érdekérvényesítő képességének más aspektusaira lásd Kelly, John: Trade union membership and power in comparative perspective. The Economic and Labour Relations Review, 2015/4, 526-544.

53 A Kúria ezt eseti döntésében is megerősítette: „a munkaidő-kedvezmény nem közvetlenül, hanem a szakszervezet rendelkezése alapján, a szakszervezeten keresztül illeti meg a szakszervezeti tisztségviselöket" (BH 2014, 345).

54 Mt. 273. § (3)-(4) bekezdés.

55 Mt. 274. § (1) bekezdés. 
ményhez hozzá kell adni. A szabály értelme és „bontása” erősen kérdéses. Egyrészt egyáltalán nem biztos, hogy a védelemre jogosult tisztségviselő képviseli a szakszervezetet a konzultáción, másrészt kifejezetten nehéz abban az esetben ezt értelmezni (adott esetben adminisztrálni), mikor a szakszervezet által egy munkavállaló teljes egészében mentesítve van (a szakzsargon ezt „függetlenítettnek” nevezi) a munkavégzés alól.

Az úgynevezett „függetlenített” szakszervezeti vezetők (amennyiben a szakszervezet taglétszáma ezt lehetővé teszi, dönthet úgy, hogy egyes tisztségviselök teljes munkaidejükben mentesüljenek munkavégzési kötelezettségük alól, és érdekképviseleti tevékenységet végezzenek) munkaidő-kedvezményének terjedelmével kapcsolatban is számos gyakorlati bizonytalanság tapasztalható. Ez különösen problematikus köztulajdonban lévő cégeknél müködő szakszervezetek esetében, ahol az Mt. (véleményem szerint alapjogilag is megkérdőjelezhető módon) ${ }^{56}$ kógens rendelkezéseket tartalmaz, melyek alapján - az uralkodó értelmezés szerint - nem adható a törvényben foglaltakon felül semmilyen külön juttatás. A munkáltatónál egyidejüleg betöltött munkakör bizonyos értelmezések szerint jogdogmatikailag is vitatható. ${ }^{57}$ A munkaidő-kedvezmény felhasználásáról (kik és milyen mértékben vehetik igénybe), ahogyan azt a Kúria egy eseti döntésében ${ }^{58}$ is megerősítette, a szakszervezet dönt, mivel az „rajta keresztül” illeti meg a szakszervezeti tisztségviselöket.

Véleményem szerint a konzultáció külön kezelése és ezáltal kvázi többletmunkaidő-kedvezmény biztosítása kedvező lehetőséget nyújt a szakszervezetek számára (különösen ott, ahol alacsony a munkavállalói létszám), ugyanakkor felesleges azt kizárólag a védelemre jogosult tisztségviselőkre alkalmazni.

\section{A „közvetlen felsőbb szakszervezeti szerv” problematikája}

Nehezen értelmezhető az Mt. 273. § (1) bekezdésének fogalomhasználata, a „közvetlen felsőbb szakszervezeti szerv" kifejezés is, amely számos ellentmondást hordoz. Ez a jogi fogalom a hozzá kapcsolódó rendelkezésekkel először az 1967. évi II. törvény 16. §-ában volt olvasható (megállapította: 1984. évi 11. törvényerejü rendelet 1. §). Történetisége azonban még messzebbröl ered; már az 1953. március 1-jén a magyar szakszervezetek XVIII. kongresszusán elfogadott, a Magyar Szakszervezetek Alapszabályai címet viselő, a Szakszervezetek Országos Tanácsa (SZOT) által kiadott dokumentum is tartalmazza az alsóbb és felsőbb szakszervezeti szerv terminológiát, mely alapján az alsóbb szakszervezeti szerv köteles végrehaj-

56 A kérdés, hogy lehet-e a köztulajdonban álló munkáltatóknál alkotmányosan eltérően szabályozni a kollektív autonómia tartalmát és határait, mint általában a munkajogban, azaz a munkáltató tulajdoni forma alapján való jogi megkülönböztetése (mint alapjogkorlátozó rendelkezés) megfelel-e az alapjog-korlátozás tesztjének (szükséges, alkalmas és arányos-e). Fodor T. Gábor-SzABó Imre Szilárd: Néhány gondolat a köztulajdonban álló munkáltatókra vonatkozó munkajogi szabályozás munkaügyi kapcsolatokra gyakorolt hatásairól. (XIV. Magyar Munkajogi Konferencia, 2017).

57 Berke Gyula előadása a Budapesti Corvinus Egyetemen 2016. november 4-én tartott, Munkaügyi kapcsolatok a „köztulajdonban álló” vállalatoknál c. szakmai fórumon.

$58 \mathrm{BH} 2014,345$. 
tani a felsőbb szerv határozatait (II. fejezet 11. c.). A szakszervezetek legfelsőbb szerve a Szakszervezetek Országos Kongresszusa volt, amely megválasztotta a Szakszervezetek Országos Tanácsát. Alatta helyezkedtek el az üzemi, területi bizottságok, a Szakszervezetek Megyei Tanácsainak közgyülései, melyek alsóbb fokú „szervei” voltak a mühely-, munkahelyi, aknai, üzemi stb. bizottságok taggyülései (II. és III. fejezet).

Ez a felépítés a Szovjetunió szakszervezeteinek alapszabályait követi mintaként, ${ }^{59}$ struktúrája és fogalomhasználata lényegileg azonos, a szakszervezeti szervek hierarchiája is ekképpen épül fel, így az alsóbb és felsőbb szakszervezeti szervek kapcsolata is. A munkajogi védettséggel kapcsolatos jogvita tekintetében érthető okokból - nem alakult ki bírói gyakorlat a szocializmus évtizedeiben. Az 1992. évi XXII. törvény lényegében a korábbi Mt. által tartalmazott rendelkezést örökítette tovább. A hatályos Mt. nem hozott érdemi változást sem tartalmában, sem fogalomhasználatában, mivel a szabályozás összhangban áll a Nemzetközi Munkaügyi Szervezet 135. számú egyezményében foglaltakkal, illetve megfelel a 143. sz. Ajánlás III. részének (5-8. pont) is, noha a védelemre jogosultak köre jelentős mértékben szükült.

Munkajogi védettség esetén a közvetlen felsöbb szakszervezeti szerv hozzájárulása szükséges a szakszervezet által az Mt. szerint meghatározott módon megjelölt tisztségviselő munkaviszonyának a munkáltató általi felmondással történő megszüntetéséhez, valamint a tisztségviselőnek a munkaszerződésétől eltérő foglalkoztatásához (kirendelés, kiküldetés, átirányítás). A szakszervezet az előzőek szerinti munkáltatói intézkedéssel kapcsolatos álláspontját a munkáltató írásbeli tájékoztatásának átvételétől számított nyolc napon belül írásban közli. ${ }^{60} \mathrm{~A}$ tájékoztatásnak, ha a szakszervezet a tervezett intézkedéssel nem ért egyet, az egyet nem értés indokait tartalmaznia kell. Ha a szakszervezet véleményét a fenti határidőn belül nem közli, úgy kell tekinteni, hogy a tervezett intézkedéssel egyetért. ${ }^{61}$ Sajátos a helyzet azonban az azonnali hatályú felmondások ${ }^{62}$ esetén - legalábbis a korábbi bírói gyakorlat szerint -, mivel az előzetes véleménykérés elmaradása az intézkedés jogellenességét nem eredményezi. Nem szükséges a szakszervezet egyetértése fegyelmező jellegủ intézkedésekhez, azaz a hátrányos jogkövetkezmény megállapításához, és értelemszerủen (a maiori ad minus) például írásbeli figyelmeztetéshez sem. ${ }^{63}$

Ugyanakkor helyesen megtartotta az új Mt. is a hozzájárulás szükségességét a munkáltatónak a tisztségviselőt érintő, Mt. 53. § szerinti intézkedéseihez.

A felek tájékoztatási kötelezettségének körében ${ }^{64}$ elvárható, hogy a szakszervezet a közvetlen felsőbb szakszervezeti szerv megnevezéséről és elérhetőségéről tájékoztassa a munkáltatót. ${ }^{65} \mathrm{Az}$ EBH 2009, 2066. számú itélet szerint, amennyiben

59 Lásd a Szovjetunió szakszervezeteinek alapszabályait. Jóváhagyva a Szovjet Szakszervezetek X. Kongresszusa által (1949. IV. 27.). Szakszervezetek Országos Tanácsa, Budapest, 1949.

60 Mt. 273. § (1)-(6) bekezdés.

61 BH 2007, 385.

62 Mt. 78. $§(1)$ bekezdés.

$63 \mathrm{BH} 1978,448$.

64 A felek tájékoztatási kötelezettsége az együttműködési kötelezettségből [Mt. 6. § (4) bekezdése] vezethető le.

65 Az Mt. 6. § (4) bekezdése, valamint az Mt. 18. §-a alapján is. 
a munkáltató kellő gondossággal megkereste a szakszervezetet a szakszervezeti tisztségviselő munkaviszonyának felmondással való megszüntetéséhez szükséges hozzájárulás megadása iránt, és azt megkapta, a perben nem értékelhető a terhére az, hogy az intézkedő szakszervezeti szerv nem volt jogosult a hozzájárulásra.

E jog gyakorlásához szükséges meghatározni azt, hogy mely szakszervezeti szerv gyakorolhatja a szakszervezeti tisztségviselő védelmével kapcsolatos nyilatkozattétel jogát. A közvetlen felsőbb szakszervezeti szervet elsősorban a szakszervezet alapszabálya rögzíti, ennek hiányában a szakszervezet nyilatkozata irányadó. Ha a választott szakszervezeti tisztséget betöltő munkavállaló munkaviszonyának felmondással történő megszüntetéséhez szükséges egyetértés megadására jogosult szervet a szakszervezet belső szabályzata nem határozza meg, a bíróság jogszerüen veszi figyelembe a szakszervezet álláspontját és az általa követett gyakorlatot. ${ }^{66}$ A gyakorlatban ezt a jogot egy alapszervezeti tisztségviselő esetében gyakorolhatja például a helyi (alapszervezeti) taggyülés, a szakszervezet ügyvezető szerve (elnökség), az ügyvezető szerv tisztségviselője felett a döntéshozó szerv (közgyűlés), de többségében a szakszervezetek tölük szervezetileg független, ágazati szövetséget vagy országos konföderációt (ágazatközi szövetséget) jelölnek meg a jognyilatkozat megtételére jogosult (egyetértési jogot gyakorló) felsőbb szervként. Jelenleg mindkét megoldás levezethető a törvény szövegéből, ugyanakkor amennyiben a jogalkotó szándéka az, hogy egy független, a konfliktustól (egy vagy akár több fokkal) „távolabb” eső, elvi szinten rögzített, kvázi független szakszervezeti szerv kezébe helyezi a védelem biztosításának lehetőségét, akkor az pontosabb meghatározást igényelne, akár tételesen felsorolva, hogy kik jogosultak a jogot gyakorolni, nevesítve az ágazati és az országos szakszervezeti szövetséget mint opciót. Ennél is praktikusabb lenne viszont az a megoldás, ami az érintett szakszervezetre bízza az egyetértést gyakorló szerv meghatározását, mindenféle strukturális („,szervi”) megkötés nélkül. A plurális szakszervezeti világban az érdekképviseletek nem feltétlenül épülnek fel ilyen mértékben hierarchikusan, mint ahogyan az a hatályos törvény szövegéből következne.

Elöremutatónak tartanám emellett az Mt. módosítását és a 273. § (6) bekezdése szerinti, a hozzájáruló nyilatkozat megtagadásával kapcsolatos viták területével bővíteni a kötelező döntőbíráskodás esetkörét. A döntőbírói eljárás jelenleg nagyon szűk körben, mindössze két esetben kötelező, ${ }^{67} \mathrm{~s}$ ebben a körben az Mt. meghatározza, hogy a felek megállapodásának hiányában a döntőbírót a felek jelöltjei közül sorsolással kell kiválasztani. ${ }^{68}$ Méltánytalannak gondolom mindezek mellett a hatályos jogi szabályozásban a szakszervezet számára biztosított rendkívül rövid, nyolcnapos határidőt, különösen más szubjektív határidőkkel (például az azonnali hatályú felmondásnál rendelkezésre álló 15 nap) összevetve.

$66 \mathrm{EBH} 2000,238$.

67 A 236. § (4) bekezdésében és a 263. §-ban foglaltakkal kapcsolatban felmerült vitában döntőbíró dönt. Ezek az üzemi tanács választásával és mủködésével kapcsolatos indokolt költségek megállapítása, valamint a jóléti célú pénzeszközök felhasználása tekintetében, ahol a munkáltató és az üzemi tanács közös döntése szükséges, de a felek megállapodása hiányában a döntőbíró eljárása kötelező.

68 Mt. 293. $§(2)$ bekezdés. 
Utalva a „felsöbb” szakszervezeti szervvel kapcsolatosan vázolt gondolatmenetre, megjegyzem, hogy ilyen rövid határidő (nyolc nap) mellett szinte lehetetlen, hogy a szakszervezet szakmailag teljes mértékben felmérje döntésének esetleges következményét. Amennyiben ráadásul egy saját „belső” szervét (közgyűlés, küldöttgyülés) jelölte meg jogosultként a jognyilatkozat megtételére, úgy kétséges lehet annak ilyen rövid időn belül történő szabályszerü összehívása is, tekintve, hogy annak határideje (rendszerint) szintén kötött, még a rendkívüliség esetében is.

A munkajogi védettség kapcsán végül arra is felhívom a figyelmet, hogy az Mt. alapján jelenleg a szakszervezet abban az esetben jogosult a megjelölt védett tisztségviselő helyett másik tisztségviselőt megjelölni, ha a tisztségviselő munkaviszonya vagy szakszervezeti tisztsége megszűnt. ${ }^{69}$ Utóbbi feleslegesen korlátozza a szakszervezetet abban, hogy változtatási igény esetén, például ha más jogcímen védetté válik a tisztségviselő (üzemi tanácsi elnökké/munkavédelmi képviselővé választják), szervezetpolitikai érdekeit megfelelően érvényesíteni tudja.

\section{5. „A szakszervezet” és „,a szövetség” A szakszervezeti szövetség kollektív szerződéskötési képességének szabályozási ellentmondásai}

Amint arról szó esett, a szakszervezet jogi személy, a típusnak megfelelő létesítő okiratán alapuló bírósági nyilvántartással jön létre, $s$ az Mt.-ben rögzített szakszervezeti jogok csak a bejegyzést követően gyakorolhatók. Az Ectv. 5. §-a feltételeket támaszt az egyesületként, így a szakszervezetként történő minősítés érdekében. A szakszervezeti jogállás alapvető feltétele e körben a rendszeres müködés, a nyilvántartott tagság és a szervezeti rend. Az egyesülési jogot nemcsak természetes személyek, hanem jogi személyek is gyakorolhatják, így hozhatók létre a szakszervezeti szövetségek, melyeknek értelemszerủen csak önállóan bejegyzett, természetes személy tagokat tömörítő szakszervezetek lehetnek a tagjai. ${ }^{70}$ Ettöl fogalmilag és tartalmát tekintve is különbözik az ún. „származtatott” jogi személy. A korábban meglehetősen áttekinthetetlen helyzetet próbálta meg rendezni az új Ptk., az ún. belső vagy más kifejezéssel élve a származékos jogalanyiság (jogi személyiség) tekintetében ${ }^{71}$ mely a szakszervezetek esetében egy szervezeti egység jogi személlyé nyilvánítását jelenti, négy konjunktív feltétel teljesülése esetén (1. A törvény ezt tegye lehetővé; 2 . Az alapszabály rendelkezzen a szervezeti egységek jogi személlyé nyilvánításáról; 3 . A szervezeti egység az alapítóktól és a jogi személytől elkülöníthető szervezettel rendelkezzen; 4. A szervezeti egység az alapítóktól és a jogi személytöl elkülöníthető vagyonnal rendelkezzen). ${ }^{72}$ Ez a belső jogalanyiság természetesen nem lehet abszolút, ehhez korlátokat az „anya jogi személy” állít.

69 Mt. 273. § (5) bekezdés.

70 Az Ectv. 4. § (3) szerint a szövetség olyan egyesület, amely két tag részvételével is alapítható, működtethető. A szövetség tagja egyesület, alapítvány, egyéb jogi személy, jogi személyiséggel nem rendelkező szervezet vagy civil társaság lehet; szövetség tagja természetes személy nem lehet.

71 SÁRKÖZY Tamás: Szervezetek jogállása az új Ptk.-ban. Gazdaság és Jog, 2011/3, 8.

72 A Ptk. 3:32. § (1) bekezdése alapján. 
A szakszervezet számára az Mt.-ben biztosított jogok a munkáltatónál képviselettel rendelkező szakszervezetet illetik meg. A munkáltatónál képviselettel rendelkező szakszervezet, amelyik alapszabálya szerint a munkáltatónál képviseletére jogosult szervet müködtet vagy tisztségviselővel rendelkezik. ${ }^{73}$ Maga a fogalom is azt feltételezi, hogy a szakszervezeti tevékenység alapvetően a munkáltatói szervezet keretei között zajlik, ahogyan a szakszervezeti jogok többsége is ezt tükrözi (gondoljunk például a szakszervezetek számára biztosított munkaidő-kedvezmény intézményére). A jogi szabályozás a munkáltatói szintről lassan három évtizede képtelen „felszabadítani” a szereplőket, de ennek okai csak részben a munkajogban keresendők. A kérdést történetileg is meghatározza az alapvetően mikroszinten szerveződő szakszervezeti mozgalom struktúrája és a kollektív alku erősen decentralizált jellege, melynél megkerülhetetlen szempont, hogy a szakszervezeti bevételek túlnyomó többsége is vállalati (nagyon kivételes esetben ágazati, alágazati) szinten realizálódik.

Ebben a rendszertani logikában számos ellentmondást hordoz a szakszervezeti szövetség lehetséges szerepe, elsősorban a kollektív szerződések megkötése és azok - különösen kötelmi jogi - alakítása terén. Véleményem szerint az Mt. amellett, hogy rendszertanát tekintve nincs összhangban az ágazati/középszintü érdekegyeztetést és kollektív szerződéskötést is szabályozó 2009. évi LXXIV. törvénnyel az ágazati párbeszédbizottságokról és a középszintű szociális párbeszéd egyes kérdéseiről (a továbbiakban: ÁPB tv.) ${ }^{74}$ önmagában is szabályozási problémával bír.

Az ÁPB tv. szemlélete a korábbi Mt. hatálya alatt alakult ki, és ezért alapvetően különbözik a hatályos Mt. által rögzített megoldástól a kollektív szerződéskötési feltételek (kellékek) tekintetében is. Az ÁPB tv. szerint az érdekképviseletek döntéshozatali jogosultságának és reprezentativitásának (kollektív szerződéskötési joggal való) meghatározása több szempont figyelembevételével, pontozásos rendszer alapján történik. ${ }^{75} \mathrm{Az}$ egyes kritériumok alapján megszerezhető maximális pontszám az adott kritériumnak megfelelő szervezetek között - arányosan, „teljesítményüknek" megfelelően - kerül felosztásra. A probléma leginkább elméleti jellegü, mivel nem alakult ki, illetve nem intézményesült megfelelően az ágazati érdekképviseleti (belső) struktúra, sem a munkaadói, sem a szakszervezeti oldalon, így az ÁPB-k jelentősége marginálissá vált.

A szakszervezeti szövetség ugyanakkor az Mt. szabályai alapján munkaszervezeti szinten akkor jogosult a kollektív szerződés megkötésére, ha a munkáltatónál képviselettel rendelkező legalább egy tagszervezete megfelel a fentiekben is taglalt feltételeknek, és tagszervezetei erre felhatalmazták. ${ }^{76}$ Tehát a szövetséget csak abban az esetben teszi jogosulttá az Mt. kollektív szerződés kötésére, ha legalább egy tagszervezete eléri a tízszázalékos küszöböt. Ez a megkötés felveti a fentebb hivatkozott ILO egyezményeknek történő teljes körü megfelelés kérdését is, ugyanis ebben az esetben arról van szó, hogy hiába bír a szakszervezeti szövetség összes-

73 Mt. 270. § (2).

74 Az ÁPB tv. szemlélete a korábbi Mt. hatálya alatt alakult ki, és ezért alapvetően különbözik a hatályos Mt. által rögzített megoldástól (a kollektív szerződéskötési feltételek tekintetében is).

75 1. számú melléklet a 2009. évi LXXIV. törvényhez.

76 Mt. 276. § (3) bekezdés. 
ségében megfelelő reprezentativitással (úgy, hogy egyes képviselettel rendelkező tagjai nem érik el a 10\%-ot), mégsem rendelkezik a kollektív szerződés megkötéséhez megfelelő alanyi kellékkel/feltétellel, egy ezt korlátozó munkajogi szabály miatt. Ez az eset elóállhat a gazdasági társaságok átalakulásával (a Ptk. szerinti összeolvadással, beolvadással), különösen azonos tevékenységet végző vállalatoknál bekövetkező szerkezeti változásokkal, például megyei/regionális gazdasági társaságok átalakításával. Ebben az esetben tehát nem arról van szó, hogy a tízszázalékos szervezettséget több szakszervezet együttesen is teljesíthesse (koalíció kötése a kollektív szerződéskötési jogosultság elérésére), ${ }^{77}$ hanem arról, hogy a szakszervezetek egy meghatározott szervezeti forma (szakszervezeti szövetség) keretében nem gyakorolhatják ezt a jogot, hiába képviselik szövetségként (amely polgári jogi szabályok szerint is egy szoros együttmüködést feltételez) a törvényileg meghatározott szervezett munkavállalói létszám (10\%) akár többszörösét. Álláspontom szerint szükséges lenne ezt a szabályt úgy módosítani, hogy a munkáltatónál szakszervezeti szövetségként működő szakszervezet tagszervezeteinek a munkáltatóval munkaviszonyban áló tagjai együttes taglétszáma legyen az irányadó a kollektív szerződéskötési jogosultság megállapításakor.

\section{A több munkáltató által megkötött kollektív szerződés alanyi kellékei (feltételei) szakszervezeti oldalról}

Ugyancsak ellentmondásosnak tartom a több munkáltató által megkötött kollektív szerződéssel kapcsolatos joganyagot. A több munkáltató által megkötött kollektív szerződés esetében a munkáltatók önállóan azonos tartalmú kollektív szerződést kötnek a náluk kollektív szerződéskötési képességgel rendelkező szakszervezettel, szakszervezetekkel. Az Mt. lehetőséget ad arra, hogy a szakszervezet(ek) a kollektív szerződést munkáltatói érdekképviseleti szervezettel kössék meg, e szervezetek (rendszerint) az Ectv. 4. § (3) bekezdése szerinti szövetség jogi formájában müködnek. ${ }^{78}$ Céljuk a tagjaik szociális és gazdasági érdekeinek előmozdítása és védelme (az Alaptörvény rendelkezései szerint). Az Mt. 276. § (1) bekezdés a) pontja alapján a munkáltatói érdekképviseleti szervezetek jogszabály szerinti megalakulása, illetve müködése mellett a kollektív szerződéskötési képességnek további kellékét is rögzíti: tagjainak fel kell hatalmazniuk az érdekképviseletet kollektív szerződés kötésére. A felhatalmazás jogi formája jellegzetesen az alapszabályban való ilyen tárgyú rendelkezés. ${ }^{79}$

77 A Versenyszféra és a Kormány Állandó Konzultációs Fóruma munkavállalói oldalának Mt. módosító javaslatai között szerepel, hogy a törvény tegye lehetővé, hogy az Mt. 276. § (2) bekezdése szerinti, tízszázalékos szervezettséget több szakszervezet együttesen is teljesíthesse (koalíció kötése a kollektív szerződéskötési jogosultság elérésére).

78 A munkáltatói érdekképviseletek létrejöttére és működésére az egyesülési jogról, a közhasznú jogállásról, valamint a civil szervezetek müködéséről és támogatásáról szóló 2011. évi CLXXV. törvény (Etv.) alkalmazandó a Polgári törvénykönyv szabályai mellett.

79 Berke Gyula-Bankó Zoltán-Szabó Imre Szilárd: Prevenció. A tanácsadás lehetősége a Munkaügyi Tanácsadó és Vitarendező Szolgálat keretében. HVG-ORAC, Budapest, 2017, 12-13. 
A munkáltatói érdekképviselet által kötött (ágazati/alágazati) kollektív szerződés esetében ${ }^{80}$ a szakszervezet kollektív szerződéskötési képességhez a hatálya alá tartozó munkáltatóknál foglalkoztatott munkavállalók tízszázalékos szervezettsége szükséges.

Kérdésként merül fel, hogy abban az esetben, amikor munkáltatói érdekképviselet köti a kollektív szerződést, a jogosultságot összességében vagy külön-külön kell-e vizsgálni az egyes munkáltatóknál a munkavállalói (szakszervezeti) oldalon, illetve hogy a jogosultság vizsgálata eltér-e abban az esetben, ha nem munkáltatói érdekképviselet köti meg a több munkáltatóra kiterjedő kollektív szerződést, hanem a munkáltatók azt önálóan teszik, érdekképviselet nélkül. A munkáltatói érdekképviselet által kötött kollektív szerződés esetében kiolvasható az a törvényböl, hogy a jogosultságot összességében kell vizsgálni [erre utal az Mt. 276. § (2) bek. b. pontjában olvasható „hatálya alá tartozó” kifejezés]; magyarán nem szükséges, hogy minden egyes munkáltatói érdekképviseleti tag foglalkoztatónál megvalósuljon a 10\%-os szakszervezeti szervezettség, a megkötött kollektív szerződés ex lege terjed ki a tagokra.

Ettől eltérően, ha nem munkáltatói érdekképviselet köti meg a több munkáltatóra kiterjedő hatályú kollektív szerződést, úgy szükséges annak a feltételnek a fennállása, amely az ún. egymunkáltatós kollektív szerződésekre is irányadó; minden egyes munkáltatóval „,szemben” szerepeljen kollektív szerződéskötési képességgel bíró szakszervezet (szakszervezetek). Így végső soron igen színes alanyi körrel bíró kollektív szerződések is létrejöhetnek, praktikus szempontok miatt (a későbbi vitás helyzetek elkerüléséért) így már a megkötésnél is külön figyelmet kell fordítani arra, hogy az esetleges későbbi módosítási igény kivel (kikkel) szemben keletkeztet tárgyalási kötelezettséget. Munkáltatói oldalról ez a kérdés nem releváns, tekintve, hogy a több munkáltató által kötött kollektív szerződés nem mutat semmilyen eltérő jellegzetességet a kollektív szerződéskötési képesség szempontjából az egy munkáltató által megkötötthöz képest. ${ }^{81}$

\section{7. Összegzés}

A fentiek is egyértelmüen világítanak rá arra a problémára, hogy milyen érzékeny kérdéseket vet fel a szakszervezet jogállásának és magának a kollektív munkajognak a szabályozása. Hosszasan lehetne még sorolni azokat az ellentmondásokat a kollektív munkajog területén (például a szakszervezeti taglétszám igazolására vonatkozó eljárások; az utólag kollektív szerződéskötési képességgel rendelkezővé váló szakszervezet helyzete; a kollektív szerződéskötési képesség elvesztése; a munkaidő-kedvezmény megállapítása, számítási módja, indokai, alkalmazási problémái; vagy éppen a köztulajdonra vonatkozó eltérő szabályozás által teremtett korlátok), amelyek a kollektív munkajogi alanyok között jog- és érdekviták forrásait jelenthetik. Megállapítható, hogy az Mt. szakszervezetekkel kapcsolatos foga-

80 Mt. 276. § (1) bekezdés.

81 BANKÓ-BERKE-KIss: i. m., 735. 
lomhasználata több, a tanulmányban is vizsgált elemében (tisztségviselö, felsőbb szerv) elszigetelt, munkajogi tartalma bizonytalan és feloldatlan, ugyanakkor polgári jogi szempontból eltérő értelmezési lehetőséget hordozó, ezért kifejezetten hasznos lenne az értelmező rendelkezések ez irányú bővítése. A szakszervezet jogállásának kérdései ugyanakkor nemcsak jogdogmatikai, de erősen jogpolitikai természetủ vitákat is felvetnek, így nagyon óvatos kritikával és javaslatokkal, de mindenekelőtt empátiával lehet hozzájuk viszonyulni a szociális párbeszéd rendszerén keresztül. Hét évvel az Mt. hatálybalépését követően indokoltnak tünik a kollektív munkajogi szabályozás felülvizsgálata.

\footnotetext{
Abstract

The unique purpose and role of trade unions is the protection of the employees' social and economic interests. As compared to the previous concept, the applicable labour code introduced a conceptually new approach with respect to collective labour law, including the purpose of trade unions, reducing the trade unions' rights to such a minimum level which shall be generally granted for a civil organization operating in the interest of a certain purpose. In my study, some legal interpretation questions - without the ambition to be exhaustive - that arise in practice come under analysis, which highlight in a crystal clear manner the question as to what sort of practical issues are raised and interpretation possibilities are opened by certain items of the Hungarian labour law regulation in connection with the legal status of the trade unions and the exercise of their rights.
} 